\title{
Antiviral Therapies and Prospects for a Cure of Chronic Hepatitis B
}

\author{
Fabien Zoulim and David Durantel \\ INSERM U1052, Cancer Research Center of Lyon, University of Lyon, Hospices Civils de Lyon, Lyon, France \\ Correspondence: fabien.zoulim@inserm.fr
}

Current therapies of chronic hepatitis $\mathrm{B}(\mathrm{CHB})$ remain limited to either pegylated interferon- $\alpha$ $($ Peg-IFN- $\alpha)$, or one of the five approved nucleoside analog (NA) treatments. Although viral suppression can be achieved in the majority of patients with high-barrier-to-resistance newgeneration NAs (i.e., entecavir and tenofovir), HBsAg loss is achieved in only $10 \%$ of patients with both classes of drugs after a follow-up of 5 years. Attempts to improve the response by administering two different NAs or a combination of NA and Peg-IFN- $\alpha$ have been unsuccessful. Therefore, there is a renewed interest to investigate a number of steps in the hepatitis $B$ virus (HBV) replication cycle and specific virus-host cell interactions as potential targets for new antivirals. Novel targets and compounds could readily be evaluated using both relevant in vitro and newly developed in vivo models of HBV infection. The addition of one or several new drugs to current regimens should offer the prospect of markedly improving the response to therapy, thus reducing the burden of drug resistance, as well as the incidence of cirrhosis and hepatocellular carcinoma (HCC).

\section{BACKGROUND-BASIS OF ANTI-HEPATITIS B VIRUS (HBV) THERAPY}

Effective therapies have been developed for Echronic hepatitis B (CHB) infection. Hence, interferon- $\alpha$ (IFN- $\alpha)$ and its pegylated form (Peg-IFN- $\alpha$ ), and five other drugs that belong to the class of nucleoside analogs (NAs), have been approved for this indication in most parts of the world (EASL 2012; Lampertico and Liaw 2012; Scaglione and Lok 2012; Jordheim et al. 2013; Buti 2014; Kao 2014). IFN- $\alpha$ is an immune modulator that induces, in a nonspecific manner, the expression of interferon-stimulated genes (ISGs) encoding intracellular or secreted proteins with direct or indirect antiviral proper- ties in both infected and noninfected cells, and promotes the differentiation/activation of immune cells (Samuel 2001; Sadler and Williams 2008). In the HBV setting, the IFN- $\alpha$ antiviral activity results from a complex mode of action including the activation of natural killer (NK)/ NKT cells, inhibition of viral genome transcription, destabilization of viral nucleocapsid, but also, as recently suggested, degradation of covalently closed circular DNA (cccDNA) via the activation of APOBEC3A in infected cells (Micco et al. 2013; Thimme and Dandri 2013; Lucifora et al. 2014).

NAs directly inhibit the reverse transcriptase activity of the HBV polymerase. The approved NAs include lamivudine (LMV), a deoxycyti-

Editors: Christoph Seeger and Stephen Locarnin

Additional Perspectives on Hepatitis B and Delta Viruses available at www.perspectivesinmedicine.org

Copyright (C) 2015 Cold Spring Harbor Laboratory Press; all rights reserved; doi: 10.1101/cshperspect.a021501

Cite this article as Cold Spring Harb Perspect Med 2015;5:a021501 
dine analog with an unnatural L conformation, and the related L-nucleoside, telbivudine (LdT; $\beta$-L-thymidine). A second group, the acyclic phosphonates, includes adefovir dipivoxil (ADV), a prodrug for the acyclic 2'-deoxy adenosine monophosphate analog adefovir, and the structurally similar tenofovir (TFV). A third group contains a D-cyclopentane sugar moiety and has the most potent anti-HBV drug discovered to date, the deoxyguanosine analog entecavir (ETV). This structural classification of NAs is useful clinically because it helps predict pathways of NA drug resistance (Zoulim and Locarnini 2009; Gish et al. 2012). In chronically HBV-infected hepatocytes, NAs inhibit the viral polymerase activity resulting in a decreased production of virions, a reduced recycling of viral nucleocapsids to the nucleus of infected cells, and theoretically a decline of viral cccDNA, although the latter can only be observed after many years of treatment (Zoulim and Locarnini 2009; Gish et al. 2012; Buti 2014). NAs do not inhibit the de novo formation of cccDNA in newly infected cells, implying that persistent residual viremia during antiviral therapy can lead to infection of new hepatocytes and reestablishment of viral cccDNA reservoir. A decrease of the total amount of intrahepatic cccDNA is observed during long-term therapy as a consequence of (1) the inhibition of the intracellular recycling pathway, (2) dilution of cccDNA via hepatocyte turnover, as cccDNA may be lost through cell division, and (3) decreased rate of infection of new cells (Moraleda et al. 1997; Le Guerhier et al. 2000, 2001; Zhu et al. 2001; Werle-Lapostolle et al. 2004).

The therapeutic efficacy of these treatments can be affected by factors, such as the development of adverse effects, poor patient compliance, previous treatment with suboptimal regimens, infection with drug-resistant viral strains, inadequate drug exposure because of pharmacologic properties of particular drug(s), and individual genetic variation (Zoulim 2011; EASL 2012; Gish et al. 2012; Lampertico and Liaw 2012; Scaglione and Lok 2012; Buti 2014; Kao 2014). A simplified view of the mode of actions of the approved antiviral agents in the HBV life cycle is shown in Figure 1.

\section{GOALS OF THERAPY AND TREATMENT END POINTS}

The goal of therapy for $\mathrm{CHB}$ is to improve the quality of life and survival by preventing or significantly delaying progression of the disease toward cirrhosis, decompensated cirrhosis, end-stage liver disease, and hepatocellular carcinoma (HCC). This goal can be achieved if HBV replication is suppressed in a sustained manner. It is accompanied by a reduction in the histological activity of $\mathrm{CHB}$ and a decreased risk of developing cirrhosis and HCC, particularly in noncirrhotic patients (EASL 2012; Lampertico and Liaw 2012; Scaglione and Lok 2012). Several recent studies in large cohorts have shown that the risk of HCC development is significantly decreased by successful antiviral therapy compared with untreated historical patient cohorts, but is not abated (Hosaka et al. 2013; Lai and Yuen 2013; Cho et al. 2014; Wu et al. 2014). Chronic HBV infection cannot be completely eradicated owing to the persistence of cccDNA in the nucleus of infected hepatocytes, which explains HBV reactivation, for instance, in patients who receive immunosuppressive therapy or chemotherapy (Werle-Lapostolle et al. 2004; Maynard et al. 2005; Wong et al. 2013; Seeger et al. 2014). Thus, therapy should at least ensure a degree of viral suppression (i.e., undetectable blood viremia) that will then lead to biochemical remission, histological improvement, and prevention of complications. This is the currently achievable end point, which can be either maintained during therapy or sustained after treatment cessation. However, the ideal end point is HBsAg loss (i.e., HBsAg seroclearance) and/or anti-HBs antibody (i.e., $\mathrm{HBs} A b)$ seroconversion, which is currently infrequently achievable with the available antiHBV agents (EASL 2012; Lampertico and Liaw 2012; Scaglione and Lok 2012; Buti 2014; Kao 2014).

\section{TREATMENT INDICATIONS}

The indications for treatment are generally the same for both $\mathrm{HBeAg}$-positive and $\mathrm{HBeAg}$ negative $\mathrm{CHB}$. This is based mainly on the com- 


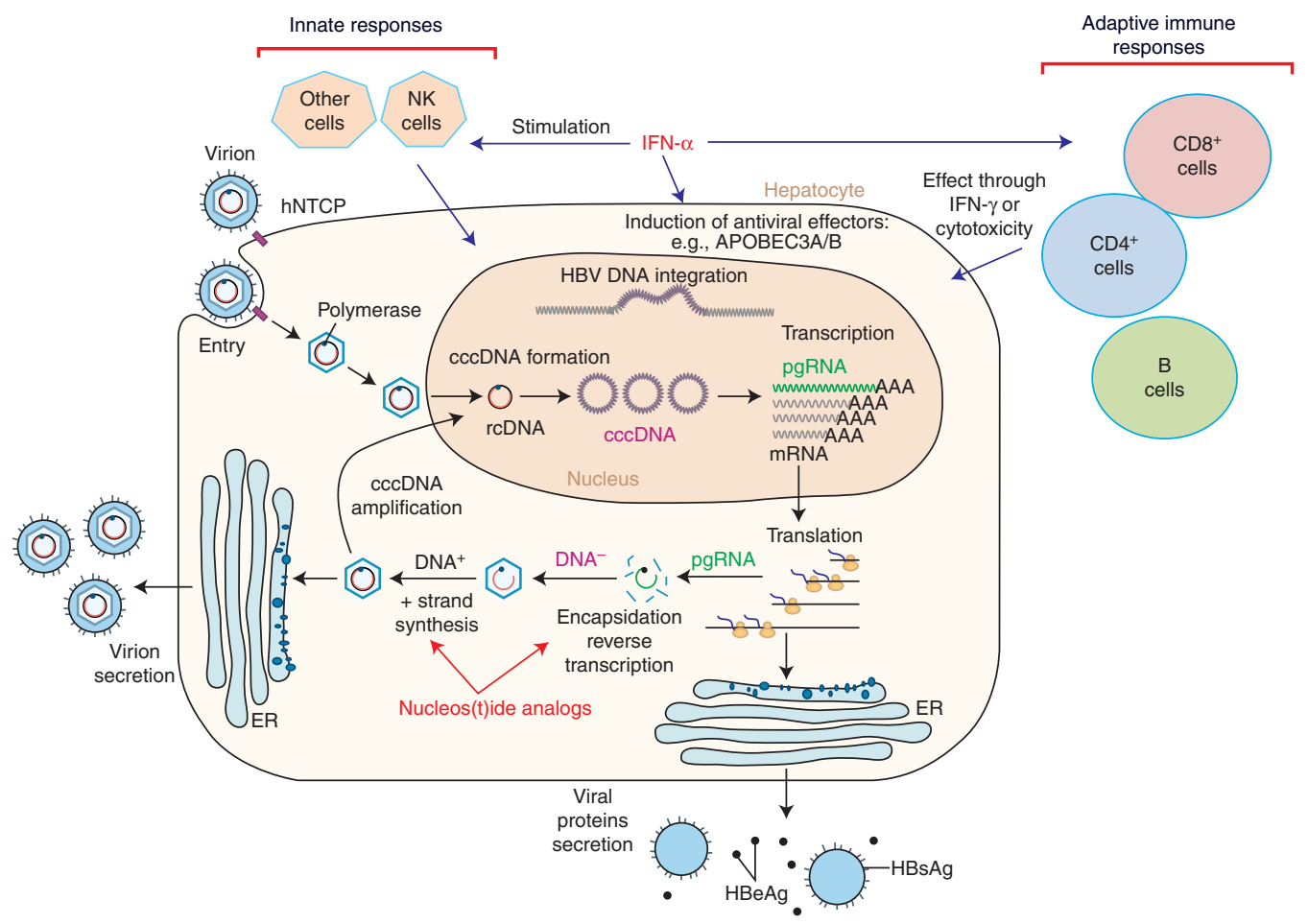

Figure 1. Schematic of interferon (IFN)- $\alpha$ and nucleoside analog (NA) modes of action. NAs block the synthesis of relaxed circular DNA (rcDNA) into neosynthesized nucleocapsids by acting as chain terminator for hepatitis $\mathrm{B}$ virus (HBV) polymerase. IFN- $\alpha$ has both direct and indirect actions on $\mathrm{HBV}$ replication in vivo. It can either (1) stimulate professional immunity cells (e.g., natural killer (NK)/natural killer T cell (NKT) and CD8 ${ }^{+}$cells) to enhance their dual mode of action, which is either noncytolytic clearance of HBV replication via the action of cytokines (e.g., IFN- $\gamma$ ) or cytolysis of infected cells, or (2) induce the expression of interferon-stimulated genes (ISG) and proteins, which can bear antiviral properties, such as APOBEC3A/B or MxA. cccDNA, covalently closed circular DNA; ER, endoplasmic reticulum; hNTCP, human sodium taurocholate cotransporting polypeptide; pgRNA, pregenomic RNA.

bination of three criteria: (1) serum HBV DNA levels, (2) serum alanine aminotransferase (ALT) levels, and (3) the severity of liver disease.

The international clinical practice guidelines from the American Association for the Study of Liver Diseases (AASLD), the European Association for the Study of the Liver (EASL), and the Asian Pacific Association for the Study of the Liver (APASL) usually recommend that patients should be considered for treatment when they have HBV DNA levels above $2000 \mathrm{IU} / \mathrm{mL}$, serum ALT levels above the upper limit of normal (ULN), and moderate to severe active necroinflammation and/or at least moderate liver fibrosis severity (EASL 2012; Lampertico and Liaw 2012; Scaglione and Lok 2012;
Buti 2014; Kao 2014). Indications for treatment may also take into account age, health status, and family history of cirrhosis or HCC, as well as extrahepatic manifestations of the disease.

The clinical management of patients also depends on their specific medical history and their clinical presentation:

1. "Immunotolerant" patients (i.e., HBeAgpositive patients under 30 years of age with persistently normal ALT levels and a high HBV DNA level) without any evidence of liver disease and without a family history of HCC or cirrhosis are currently not considered by the guidelines for liver histology assessment or therapy, but a clinical follow-up every 6 mo is recommended. In patients $>30$ 
years of age and/or with a family history of HCC or cirrhosis, both evaluation of liver histology and treatment may be considered.

2. Patients with obviously active $\mathrm{CHB}$ (i.e., HBeAg-positive and HBeAg-negative patients with ALT above 2 times ULN and serum HBV DNA above $2000 \mathrm{IU} / \mathrm{mL}$ ) may start treatment even without a liver biopsy, as it would not be mandatory for a treatment decision. A noninvasive method for the estimation of the extent of fibrosis/cirrhosis is extremely useful in patients who start treatment without liver biopsy, to implement screening of HCC and portal hypertension.

3. HBeAg-negative patients with persistently normal ALT levels and HBV DNA levels above 2000 but below 20,000 IU/mL, without any clinical evidence of liver disease, are currently not considered for liver biopsy or therapy. However, a close follow-up of ALT and HBV DNA is recommended.

4. Patients with compensated cirrhosis and detectable HBV DNA must be considered for treatment even if ALT levels are normal.

5. Patients with decompensated cirrhosis and detectable HBV DNA require urgent antiviral treatment with NAs. Significant clinical improvement can be associated with control of viral replication (Liaw et al. 2011a,b). However, antiviral therapy may not be sufficient to rescue some patients with very advanced liver disease who should be considered for liver transplantation at the same time.

6. Inactive carriers receiving chemotherapy or other immune suppressant treatments need to receive preemptive antiviral therapy to prevent viral reactivation, implying that $\mathrm{HBV}$ screening is mandatory for these patients before starting immune suppressant therapy.

7. HIV-coinfected patients should be treated with treatment regimens including a high barrier-to-resistance NA active on both HIV and $\mathrm{HBV}$ (i.e., TFV). The antiviral regimen should meet current highly active antiretroviral therapy (HAART) criteria for effective HIV management including adequate viral suppression.

\section{RESULTS OF INTERFERON AND NA THERAPIES}

The efficacy of antiviral drugs has been assessed mainly at 1 year in large randomized controlled trials and has been reviewed recently (EASL 2012; Lampertico and Liaw 2012; Scaglione and Lok 2012; Buti 2014; Kao 2014). Longerterm results are now available from extension of randomized trials, sometime in patient subgroups and from several cohort studies (Hosaka et al. 2013; Lai and Yuen 2013; Cho et al. 2014; Wu et al. 2014). Table 1 shows the response rates with Peg-IFN- $\alpha$, TFV, and ETV from different trials. These trials used different HBV DNA assays and there are no head-to-head comparisons for all the drugs.

\section{HBeAg-Positive Patients}

Response rates, including HBV DNA undetectability and anti-HBe seroconversion, at $6 \mathrm{mo}$ following 48 wk of Peg-IFN- $\alpha$ and at $1 \mathrm{yr}$ of NA therapy are shown in Table 1 . Anti-HBe seroconversion rates were of the order of $30 \%$ with Peg-IFN- $\alpha$ and $\sim 20 \%$ with NAs after $1 \mathrm{yr}$ of therapy (Buti 2014; Kao 2014). In adherentto-treatment patients, a virological remission rate of $>90 \%$ can be maintained with either ETV or TFV with prolonged therapy (Gish et al. 2007; Heathcote et al. 2011; Lok et al. 2012; Ono et al. 2012; Gordon et al. 2013; Fung et al. 2014; Kitrinos et al. 2014). Rates of HBsAg loss following 12 mo of treatment were $3 \%-7 \%$ with Peg-IFN- $\alpha$, $1 \%$ with LMV, 0\% with adefovir, $2 \%$ with ETV, $0.5 \%$ with LdT, and 3\% with TFV (Buti 2014; Kao 2014). HBsAg loss rates increase after the end of PegIFN- $\alpha$ therapy in patients with sustained offtreatment virological response and with prolongation of NA therapy, and reach $\sim 10 \%$ after $5 \mathrm{yr}$ of follow-up for Peg-IFN- $\alpha$ or of continuous NA treatment (Kao 2014).

\section{HBeAg-Negative Patients}

Response rates at 6 mo following 48 wk of PegIFN- $\alpha$ and at 12 mo of NA therapy are shown in 
Table 1. Results at 48 weeks

\begin{tabular}{lccc}
\hline & Entecavir $^{\mathrm{a}}$ & Tenofovir $^{\mathrm{b}}$ & ${\text { PEG-IFN- } \alpha-2 \mathrm{a}^{\mathrm{c}}}^{\mathrm{c}}$ \\
\hline HBeAg positive & $n=354$ & $n=176$ & $n=271$ \\
HBV DNA undetectable & $67 \%$ & $76 \%$ & $25 \%^{\mathrm{d}}$ \\
HBeAg seroconversion & $21 \%$ & $21 \%$ & $27 \%$ \\
ALT normalization & $68 \%$ & $68 \%$ & $39 \%$ \\
HBsAg loss & $2 \%$ & $3.2 \%$ & $2.9 \%^{\mathrm{e}}$ \\
HBeAg negative & $n=325$ & $n=250$ & $n=177$ \\
HBV DNA undetectable & $90 \%$ & $93 \%$ & $63 \%^{\mathrm{d}}$ \\
ALT normalization & $78 \%$ & $76 \%$ & $38 \%$ \\
HBsAg loss & $0.3 \%$ & $0 \%$ & $0.6 \%{ }^{\mathrm{e}}$ \\
\hline
\end{tabular}

ALT, Alanine aminotransferase; HBV, hepatitis B virus.

${ }^{a}$ Chang et al. 2006.

${ }^{\mathrm{b}}$ Lai et al. 2006; Marcellin et al. 2008.

${ }^{c}$ Lau et al. 2005; Marcellin et al. 2004.

${ }^{\mathrm{d}}$ HBV DNA $<400$ copies/mL.

${ }^{\mathrm{e}}$ At 72 wk.

Table 1 (Vigano et al. 2014; Vlachogiannakos and Papatheodoridis 2014). Rates of sustained off-treatment virological response were of the order of $20 \%$ at 6 mo following $12 \mathrm{mo}$ of PegIFN- $\alpha$ therapy and $<5 \%$ following discontinuation of 12 mo of NA therapy. In adherent-totreatment patients, a virological remission rate of $>95 \%$ can be maintained with either continuous ETV or TFV administration (Vigano et al. 2014). Rates of HBsAg loss following 12 mo of treatment were $3 \%$ with Peg-IFN- $\alpha$ (at 6 mo after the end of therapy) and $0 \%$ with LMV, adefovir, ETV, LdT, or TFV. HBsAg loss rates increase to $9 \%$ at $3 \mathrm{yr}$ and $12 \%$ at $5 \mathrm{yr}$ following Peg-IFN- $\alpha$ therapy. In contrast, HBsAg loss is rarely observed during the first $5 \mathrm{yr}$ of NA therapy in HBeAg-negative CHB patients (Vigano et al. 2014).

\section{PREDICTORS OF TREATMENT RESPONSE}

Certain general baseline and on-treatment predictors of subsequent response have been identified. Predictors of response for the existing antiviral therapies at various time points vary for different agents. Predictors may be useful to guide initiation and continuation of antiviral therapy.

\section{HBeAg-Positive Patients}

\section{Pretreatment Factors}

Predictors of anti-HBe seroconversion for both Peg-IFN- $\alpha$ and NAs are low viral load (HBV DNA below $2 \times 10^{8} \mathrm{IU} / \mathrm{mL}$ ), high serum ALT levels (above $2-5$ times ULN), and high activity scores on liver biopsy (EASL 2012; Lampertico and Liaw 2012; Scaglione and Lok 2012; Buti 2014; Kao 2014). HBV genotypes A and B have been shown to be associated with higher rates of anti-HBe seroconversion and HBsAg loss than genotypes $\mathrm{D}$ and $\mathrm{C}$, respectively, after treatment with Peg-IFN- $\alpha$. HBV genotype does not influence the virological response to any NAs, except genotype $\mathrm{A}$, which is associated with a higher rate of HBsAg loss in TFV-treated patients.

\section{On-Treatment Factors}

In HBeAg-positive CHB treated with Peg-IFN$\alpha$, an HBV DNA decrease to $<20,000 \mathrm{IU} / \mathrm{mL}$ at $12 \mathrm{wk}$ is associated with a $50 \%$ chance of antiHBe seroconversion, and ALT flares followed by a HBV DNA decrease are associated with more frequent anti-HBe seroconversion. A decline of HBsAg levels below $1500 \mathrm{IU} / \mathrm{mL}$ at $12 \mathrm{wk}$ is a strong predictor of anti-HBe seroconversion, whereas HBsAg levels $>20,000 \mathrm{IU} / \mathrm{mL}$ or no 
decline of HBsAg levels at $12 \mathrm{wk}$ are associated with a very low probability of subsequent antiHBe seroconversion.

Virological response (undetectable HBV DNA) at 24 wk during treatment with LMV or LdT and at 48 wk during treatment with adefovir is associated with a lower incidence of resistance (i.e., an improved chance of maintained virological response) in both $\mathrm{HBeAg}$-positive and $\mathrm{HBeAg}$-negative patients and with a higher chance of anti-HBe seroconversion in HBeAgpositive patients. A decline of HBsAg during NA treatment in HBeAg-positive patients may identify cases with subsequent HBeAg or HBsAg loss.

\section{HBeAG-Negative Patients}

\section{Pretreatment Factors}

In $\mathrm{HBeAg}$-negative $\mathrm{CHB}$, there are no strong pretreatment predictors of virological response for Peg-IFN- $\alpha$ and NAs (EASL 2012; Lampertico and Liaw 2012; Vigano et al. 2014; Vlachogiannakos and Papatheodoridis 2014).

\section{On-Treatment Factors}

In HBeAg-negative CHB treated with Peg-IFN$\alpha$, HBV DNA decrease to $<20,000 \mathrm{IU} / \mathrm{mL}$ at 12 wk has been reported to be associated with a $50 \%$ chance of sustained off-treatment response. A combination of no HBsAg decline and $<2 \log _{10} \mathrm{IU} / \mathrm{mL}$ decline of HBV DNA seems to be a predictor of nonresponse in European HBeAg-negative patients with genotype D. Several recent reports showed that HBsAg decline is predictive of sustained off-treatment virological response and HBsAg loss. However, further studies are needed to clarify how to optimize the use of HBsAg levels in the management of patients in clinical practice. In patients receiving NAs, maintained viral suppression is required to prevent the emergence of antiviral drug-resistant strains.

\section{Treatment Strategies}

Currently, there are two different treatment strategies for both $\mathrm{HBeAg}$-positive and $\mathrm{HBeAg}$ negative $\mathrm{CHB}$ patients: (1) treatment of finite duration with Peg-IFN- $\alpha$ or an NA, and (2) long-term treatment with NAs (EASL 2012; Lampertico and Liaw 2012; Scaglione and Lok 2012; Buti 2014; Kao 2014; Vigano et al. 2014; Vlachogiannakos and Papatheodoridis 2014).

The main theoretical advantages of PegIFN- $\alpha$ are the absence of resistance and the potential for immune-mediated control of HBV infection with an opportunity to obtain a sustained virological response off-treatment and a chance of HBsAg loss in patients who achieve and maintain undetectable HBV DNA. Frequent side effects and subcutaneous injection are the main disadvantages of Peg-IFN- $\alpha$ treatment. Peg-IFN- $\alpha$ is contraindicated in patients with decompensated HBV-related cirrhosis or autoimmune disease, in patients with uncontrolled severe depression or psychosis, and in female patients during pregnancy. ETV and TFV are potent HBV inhibitors with a high barrier to resistance. Thus, they can be confidently used as first-line monotherapies (Zoulim and Locarnini 2009; Gish et al. 2012).

The other three NAs may only be used in the treatment of $\mathrm{CHB}$ if more potent drugs with a high barrier to resistance are not available. LMV is an inexpensive agent, but engenders very high rates of resistance with long-term monotherapy. Adefovir is less efficacious and more expensive than TFV, leading to higher rates of resistance. LdT is a potent inhibitor of HBV (Sun et al. 2014), but owing to a lower barrier to resistance, a high incidence of resistance has been observed in patients with high baseline HBV DNA levels and in those with detectable HBV DNA after 6 mo of therapy; resistance rates to LdT are relatively low in patients who achieve undetectable HBV DNA after 6 mo of therapy. Recent retrospective studies suggest that long-term LdT therapy may improve kidney functions assessed by the estimated glomerular filtration rate (Gane et al. 2014).

\section{Treatment of Finite Duration with PEG-IFN or an NA}

This strategy is intended to achieve a sustained off-treatment virological response. A 48-wk course of Peg-IFN- $\alpha$ is mainly recommended 
for HBeAg-positive patients with the best chance of anti-HBe seroconversion. It is practically the only option that may offer a chance for sustained off-treatment response after a finite duration of therapy. In $\mathrm{HBeAg-negative} \mathrm{pa-}$ tients, Peg-IFN- $\alpha$ therapy can achieve on-treatment viral suppression, but is followed by virological relapse after treatment cessation in many patients.

Finite-duration treatment with an NA is achievable for $\mathrm{HBeAg}$-positive patients who seroconvert to anti-HBe on treatment. However, treatment duration is unpredictable before therapy as it depends on the timing of anti-HBe seroconversion and the treatment continuation after anti-HBe seroconversion. Anti-HBe seroconversion may not be durable after NAs discontinuation in a substantial proportion of these patients, therefore requiring close virologic monitoring after treatment cessation. Even after NA treatment prolongation for an additional 12 mo after anti-HBe seroconversion, a durable off-treatment response can be expected in $40 \%-80 \%$ of these patients.

\section{Long-Term Treatment with NAs}

This strategy is necessary for patients who are not expected to or failed to achieve a sustained
Antiviral Therapies of Chronic HBV Infections

off-treatment virological response and require extended therapy (i.e., for HBeAg-positive patients who do not develop anti-HBe seroconversion and HBeAg-negative patients) (Buti 2014; Vigano et al. 2014). This strategy is also recommended in patients with cirrhosis irrespective of HBeAg status or anti-HBe seroconversion on treatment. The most potent drugs with the optimal resistance profile (i.e., TFV or ETV), should be used as first-line monotherapies. It is optimal to achieve and maintain an undetectable HBV DNA level tested by real-time polymerase chain reaction (PCR), whatever the drug used. Treatment with either TFV or ETV monotherapy for $\geq 5$ yr achieves maintained virological remission in the vast majority of patients.

\section{RESISTANCE TO ANTIVIRAL DRUGS AND TREATMENT FAILURE}

\section{Main Concepts}

The development of drug resistance begins with mutations in the polymerase gene, followed by an increase in viral load, an increase in serum ALT levels several weeks to months later, and progression of liver disease (Zoulim and Locarnini 2009; Gish et al. 2012). The main mutations associated with resistance to a given NA are

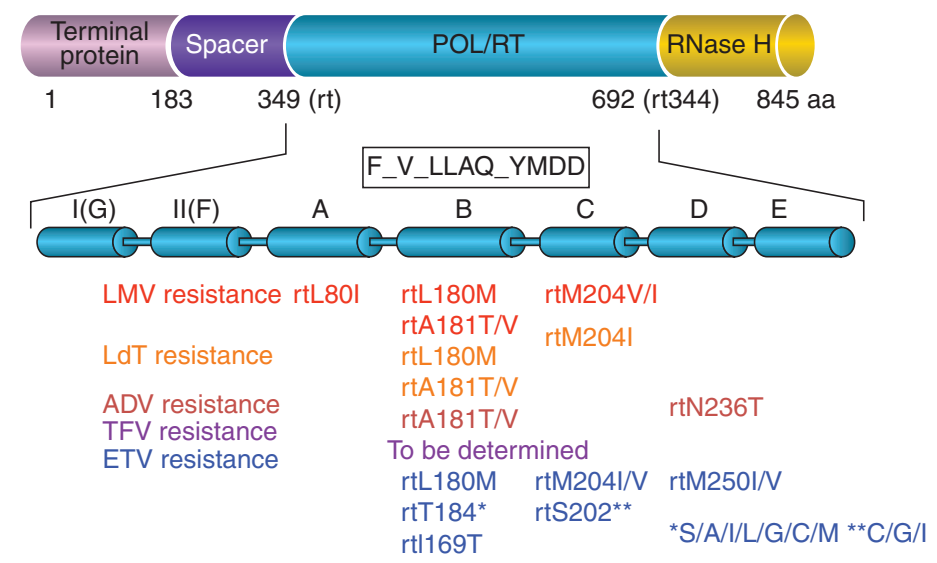

Figure 2. Position of resistance mutations within hepatitis B virus (HBV) polymerase. Mutations conferring resistance to the five approved nucleoside analogs (NAs) are located within the subdomains A, B, C, and D of HBV polymerase. Some mutations confer resistance to different NAs; this cross-resistance profile is to be taken into consideration for the clinical management of patients. ADV, Adefovir dipivoxil; ETV, entecavir; LdT, telbivudine; LMV, lamivudine; POL/RT, reverse transcriptase domain of HBV polymerase; TFV, tenofovir. 
shown in Figure 2. The appearance of mutation in vivo can be monitored by direct sequencing (including next-generation sequencing), sequencing after cloning, or by hybridization techniques, and mutants can be phenotyped in vitro by previously described techniques (Durantel et al. 2005; Liu and Kitrinos 2013). In patients with LMV resistance, the risk of increased serum ALT is usually correlated with the duration of detectability of the resistant strain (Lok et al. 2003). These patients are also at significant risk of ALT flare, which may be accompanied by hepatic decompensation (Lok et al. 2003). The detrimental effect of HBV drug resistance on liver histology (Dienstag et al. 2003) and then on clinical outcome was shown by a trial of LMV in patients with advanced fibrosis (Liaw et al. 2004). In contrast to LMV, the kinetics of emergence of resistance to ADV are typically slower, but follow the same sequence of events (Hadziyannis et al. 2006). In some cases, the emergence of ADV resistance is also associated with acute exacerbation of disease and liver failure (Fung et al. 2005). Only limited data are available on the clinical outcome of patients who are infected with LdT-, ETV-, or TFV-resistant HBV, mainly because treatment adaptation, usually based on in vitro cross-resistance data, has been initiated much earlier.

The availability of antiviral drugs with complementary cross-resistance profiles (Fig. 2) allows physicians to adapt antiviral therapy according to the virological situation to prevent the clinical deterioration resulting from the emergence of resistance. There are several clinical risk factors associated with the development of NA resistance, including high levels of serum HBV DNA, high serum ALT levels, and high body mass index. Prior therapy with NAs, and inadequate viral suppression during therapy also predict drug resistance.

Typically, the development of NA resistance depends on the following factors (Zoulim and Locarnini 2009; Gish et al. 2012): (1) rate of virus replication; (2) complexity and diversity of the viral quasispecies; (3) selective pressure exerted by the NA (potency); (4) viral replication space in the liver; (5) replication fitness of the emerging NA-resistant HBV; (6) genetic barrier to re- sistance of the NA; (7) previous treatment history and archiving of drug-resistant strains; and (8) treatment observance/compliance. This explains that sequential therapy with low-barrierto-resistance NA sharing cross-resistance may favor the emergence of multiresistant strains that may explain, for instance, failure to ETV therapy after an initial resistance to LMV or LdT (Villet et al. 2007; Liu et al. 2010).

\section{Clinical Aspects of Resistance and Treatment Failure}

All patients receiving NA therapy for $\mathrm{CHB}$ should be closely monitored for virologic response and breakthrough during treatment. Serum HBV DNA should be tested every 3 mo during treatment; however, if the patient is compliant and a high genetic barrier, high potency drug (ETVand TFV) is used, then this frequency can be reduced to $6 \mathrm{mo}$. In a compliant patient, it is important to distinguish between primary nonresponse, partial virologic response, and virologic breakthrough (viral rebound) owing to underlying antiviral drug resistance, as it has implications for treatment adaptation (Zoulim and Locarnini 2009; Gish et al. 2012).

1. Primary nonresponse. The failure to achieve a $1.0 \log _{10} \mathrm{IU} / \mathrm{mL}$ decline in viral load after $12 \mathrm{wk}$ of therapy is considered as a primary nonresponse. It may be owing to a lack of compliance or the medication may not use its antiviral activity in a particular individual. Suboptimal response was often seen with $\mathrm{ADV}$ and was shown to be unrelated to a reduced drug susceptibility of viral strains as measured in vitro by phenotypic assay (Carrouee-Durantel et al. 2008). With the advent of more potent antiviral drugs, such as TFV and ETV, this phenomenon is now much less frequent. When a primary nonresponse is identified, treatment should be modified to prevent disease progression and subsequent risk of emergence of drug-resistant mutants.

2. Partial response. The recommendations of international clinical practice guidelines are to achieve undetectable HBV DNA during therapy; therefore, partial response is de- 
fined by detectable HBV DNA using a realtime PCR assay during continuous therapy (EASL 2012; Lampertico and Liaw 2012; Scaglione and Lok 2012). With antiviral drugs that have a low genetic barrier to resistance (LMV, LdT), the lack of complete antiviral response at wk 24 of therapy was shown to predict the subsequent resistance rate. With the more potent and high genetic barrier drugs, such as ETV and TFV, the rate of undetectable HBV DNA after $1 \mathrm{yr}$ of therapy is significantly improved, reaching $\sim 70 \%$ in $\mathrm{HBeAg}$-positive patients and $90 \%$ in HBeAg-negative patients (Buti 2014; Vigano et al. 2014). Because the rate of viral suppression continues to increase over time with ETV and TFV, the timing of treatment adaptation mainly depends on the kinetics of viral load decay, especially in patients starting from a very high viral load who may just need additional weeks of therapy to reach undetectable HBV DNA by PCR testing (Buti 2014; Vigano et al. 2014). Therefore, the pattern of viral load decline is more useful than a single assessment, because the latter may result in a misleading interpretation of treatment response. When using drugs with a low barrier to resistance, it is recommended that in cases of persisting low viremia, treatment be adapted to maximize viral suppression and minimize the subsequent risk of emergence of resistance (Zoulim and Locarnini 2009; Gish et al. 2012). In the case of NA with high barrier to resistance (TFV and ETV), the continuation of the same treatment associated with counseling on treatment compliance may allow one to reach complete virological response several weeks later (Zoulim and Locarnini 2009; Gish et al. 2012).

3. Virologic breakthrough and rebound. Virologic breakthrough typically results from the emergence of drug-resistant viral strains. It is defined by an increase of at least $1.0 \log _{10}$ $\mathrm{IU} / \mathrm{mL}$ compared with the lowest value achieved during treatment, confirmed by a second test, in a treatment-compliant patient. It usually follows the detection of re-
Antiviral Therapies of Chronic HBV Infections

sistance mutations (Zoulim and Locarnini 2009; Gish et al. 2012). In the absence of treatment adaptation, the increase in viremia may be followed by an increase in ALT levels (biochemical breakthrough) and subsequently progression of liver disease (clinical breakthrough) (Zoulim and Locarnini 2009; Gish et al. 2012). The increase of viral load associated with the emergence of resistance mutations depends on the fitness of the mutants; interestingly, it was shown that resistance mutations in the polymerase gene affecting the overlapping surface gene (e.g., rtA181T/sW172*) may affect both their capacity to be secreted from infected hepatocytes and their infectivity (Warner and Locarnini 2008; Billioud et al. 2011). This may result in a slow increase of viral load for which the identification of a $1 \log _{10} \mathrm{IU} / \mathrm{mL}$ increase may be difficult.

\section{Management of Treatment Failure}

\section{Assessment of Treatment Adherence}

Good adherence to anti-HBV therapies is important for maintaining maximal suppression of HBV replication (Table 2). Poor adherence can result in substantially reduced plasma drug levels, depending on the number of doses missed and the half-life of the drug, and can result in increased viral replication (Zoulim and Locarnini 2009; Gish et al. 2012). Investigation of adherence to NA therapy in patients with CHB has shown that nearly $40 \%$ may not be fully adherent; this significantly impacts on the rates of viral suppression (Sogni et al. 2012). Low-level viral replication associated with nonadherence increases the pressure on the potency of the NA, and consequently increases the risk of selecting for resistance. Specific treatment adherence questionnaires and drug concentration monitoring can be useful for the management of patients. The level of education, type of health insurance, cultural factors, as well as low copayment for medications can significantly impact medication adherence. Thus, programs on patient counseling and on medication adherence to improve effectiveness of antiviral therapy in clinical practice are recommended. 
F. Zoulim and D. Durantel

Table 2. Management of treatment failure

\begin{tabular}{|c|c|}
\hline Type of failure & Treatment adaptation \\
\hline $\begin{array}{l}\text { Lamivudine } \\
\text { resistance }\end{array}$ & $\begin{array}{l}\text { (1) Add TFV (add ADV if TFV not available). (2) A switch to TFV is also advised by some } \\
\text { guidelines. (3) A switch to ADV is not recommended owing to a high rate of } \\
\text { resistance and its low potency. }\end{array}$ \\
\hline Adefovir resistance & $\begin{array}{l}\text { (1) Switch to TFV if available and add a second drug without cross-resistance. (2) If no } \\
\text { history of LMV, switching to ETV is also effective. (3) If rtN236T substitution, } \\
\text { consider adding LMV, ETV, or LdT to the TFV or switch to TFV plus FTC; if no } \\
\text { history of LMV prior, consider switching to ETV. (4) If rtA181 V/T substitution, } \\
\text { alone or in combination with rtN236T, switch to TFV plus ETV; as before, if no } \\
\text { history of LMV, consider switching to ETV. }\end{array}$ \\
\hline $\begin{array}{l}\text { Telbivudine } \\
\text { resistance }\end{array}$ & $\begin{array}{l}\text { (1) Add TFV. (2) A switch to TFV has also been considered in some guidelines. (3) A } \\
\text { switch to ADV is not recommended. }\end{array}$ \\
\hline Entecavir resistance & (1) Add TFV. (2) A switch to TFV can also be considered. \\
\hline Tenofovir resistance & $\begin{array}{l}\text { (1) Not been confirmed so far. (2) Genotyping and phenotyping required. (3) May add } \\
\text { ETV. }\end{array}$ \\
\hline
\end{tabular}

ADV, Adefovir dipivoxil; ETV, entecavir; LdT, telbivudine; LMV, lamivudine; TFV, tenofovir.

\section{Treatment Adaptation According to Cross-Resistance}

Cross-resistance is defined as resistance to drugs to which a virus has never been exposed as a result of changes that have been selected for by the use of another drug (Zoulim and Locarnini 2009; Gish et al. 2012). The resistance-associated mutations selected by a particular NA confer at least some degree of cross-resistance to other members of its structural group but may also diminish the sensitivity to NAs from a different chemical group. The initial drug choice and subsequent rescue therapies should be based on the knowledge of cross-resistance, so that the second agent has a different resistance profile to the initial failing agent. This is particularly important because drug-resistant mutants that have been selected by previous treatments are thought to be archived in viral cccDNA reservoirs in the liver (Zoulim and Locarnini 2009; Gish et al. 2012). The add-on strategy with NAs having complementary cross-resistance profiles is mandatory when using drugs with a low barrier to resistance.

\section{Management of Antiviral Drug Resistance}

Virologic breakthrough in compliant patients is related to viral resistance. Resistance should be identified as early as possible, before ALT levels increase, by monitoring HBV DNA levels and if possible identifying the NA resistance profile; the best therapeutic strategy can then be determined based on this information. Clinical and virological studies have shown the benefit of an early adaptation of treatment (Zoulim and Locarnini 2009; Gish et al. 2012). In case of resistance, an appropriate rescue therapy should be initiated as soon as possible. Adding a second drug that is not in the same cross-resistance group as the first (i.e., L-nucleoside vs. acyclic phosphonate vs. D-cyclopentane) is recommended at least for drugs with a low barrier to resistance. However, although there is a strong virologic rationale for an add-on strategy with a complementary drug to prevent the emergence of multidrug-resistant strains and raise the barrier to resistance, there is a current trend to recommend a switch to a complementary drug having a high barrier to resistance, such as TFV (Berg et al. 2014). This critical point will need a precise evaluation by long-term clinical and molecular virology studies, as some mutants are associated with slow decline of viral load (Villet et al. 2008; Patterson et al. 2011; Lavocat et al. 2013). Furthermore, the switch strategy does not apply to patients who have been exposed to multiple alternating monotherapies; these patients should be enrolled in add-on strategies to minimize the risk of subse- 
quent treatment failure, especially in the presence of underlying cirrhosis. Figure 2 shows the major resistance substitutions; cross-resistance can be inferred from these profiles for the most frequent resistant HBV variants and treatment adaptation should be performed accordingly (Zoulim and Locarnini 2009; Gish et al. 2012).

\section{REASONS TO CONSIDER "EARLY" TREATMENT INTERVENTION}

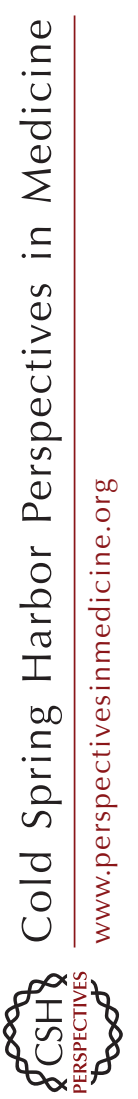

Current international treatment guidelines recommend delaying therapy until patients show clear signs of active liver disease extending over several months, including persistent ALT elevations and, when biopsies are available, evidence of inflammation and/or fibrosis (EASL 2012; Lampertico and Liaw 2012; Scaglione and Lok 2012). These guidelines, if rigorously applied, should identify patients entering the immune reactive phase, when synergy with the host response can maximize therapeutic outcomes of antiviral therapy, hopefully with $\mathrm{HBeAg}$ and, ideally, HBsAg seroconversion. Application of the guidelines can block the progression of fibrosis and cirrhosis and may reduce the rate of progression to HCC (Hosaka et al. 2013; Lai and Yuen 2013; Cho et al. 2014; Wu et al. 2014).

An important placebo control trial was performed with LMV to determine its efficacy on clinical end points. Patients enrolled for this study had significant liver disease and advanced fibrosis. A $>50 \%$ reduction in liver disease progression including HCC was found after 36 mo of therapy (Liaw et al. 2004). This study was a first proof of concept that antiviral therapy of $\mathrm{CHB}$ even at late stages can decrease the major complications of chronic infection (Liaw et al. 2004). Other studies suggested a trend for a lower incidence of HCC in patients treated with LMV for chronic hepatitis compared with those treated at the stage of cirrhosis (Papatheodoridis et al. 2011). It is important to remember, however, that the HCC incidence in these $\mathrm{CHB}$ patients treated with NAs was significantly decreased but not eliminated (Papatheodoridis et al. 2011; Hosaka et al. 2013; Lai and Yuen 2013; Cho et al. 2014; Wu et al. 2014). Strict adherence to clinical guidelines requires a level of clinical monitoring, public awareness, and case ascertainment that will be difficult to achieve as long as young adults think they are not yet at risk and possibly in need of treatment to reduce the incidence of cirrhosis and HCC later in life. Another important concern is that HCC risk factors in HBV carriers are not well understood. Current thinking favors the notion that the HCC risk begins, in the vast majority of cases, with the immune reactive phase, but there is no proof that it does not begin much earlier.

The current information on long-term antiviral treatment efficacy and safety allows one to consider earlier treatment intervention in patients with chronic HBV infection. A change in treatment practices is much more feasible than it was even a few years ago, as much better drugs have become available with a better antiviral potency and a higher barrier to resistance. It is interesting to see that the results of the first clinical trial of NAs in immune-tolerant patients has recently been published (Chan et al. 2014) and showed a significant drop in viremia levels in the majority of patients, although no HBsAg seroconversion occurred and the impact on HCC development could not be determined owing to the short duration of follow-up. In theory, it would be best to initiate NA treatment in all immune-tolerant patients. However, a more conservative approach, which would be one step beyond the current guidelines, would be to propose therapy in all patients with persistently high-normal ALT levels, or with normal ALTs who show relatively low levels of viremia (e.g., $>10^{4}$ but $\leq 10^{8}$ copies per $\mathrm{mL}$ ), including patients in their 20s, not just those beyond $40 \mathrm{yr}$ of age (Lai et al. 2007; Zoulim and Mason 2012). When biopsies are available, attempts should be made to establish hepatocyte infection levels and identify lowlevel inflammatory activity. The presence of some degree of inflammatory activity associated with a reduction of $\mathrm{HBV}$ capsid/core protein (HBc) Ag-positive hepatocytes, and lower levels of HBV DNA in serum $(<8 \log 10 \mathrm{IU} / \mathrm{mL}$, but $>4 \log 10 \mathrm{IU} / \mathrm{mL}$ ) would suggest a high level of accumulated hepatocyte damage/change, even in the absence of other indicators of histological change, and treatment would seem strongly 
warranted. This is also supported by the observation that $\mathrm{HBV}$-specific T-cell functions are conserved in patients in the so-called "immune tolerance" phase (Kennedy et al. 2012). An unappreciated cause of clonal hepatocyte repopulation occurs in noncirrhotic liver as well. Immune killing of infected hepatocytes is the strongest known pressure on the infected hepatocyte population in the noncirrhotic liver and, analogous to cirrhosis, should lead to the emergence of HBV-resistant hepatocytes that are able, in this example, to avoid immune killing. Indeed, most analyses of long-term carriers suggest that $50 \%$ or more of hepatocytes no longer support HBV infection and/or support much reduced levels of replication (Mason et al. 2008). Therefore, although it may seem paradoxical at first glance, any reduction in HBV titers in HBV carriers may warrant initiation of antiviral therapy, even if biopsy does not reveal histologically detectable active hepatitis (Zoulim and Mason 2012).

\section{TOWARD A CURE OF HBV INFECTION WITH NOVEL COMBINATION STRATEGIES?}

One of the major questions regarding antiviral therapy of $\mathrm{CHB}$ was whether the combination of Peg-IFN- $\alpha$ with NAs could improve the offtreatment response rate and the rate of HBsAg seroconversion to shorten treatment duration. However, despite the observation that the combination of Peg-IFN- $\alpha$ with LMV or LdT showed a higher on-treatment virological response, it did not show a higher rate of sustained off-treatment virological or serological response (Marcellin et al. 2004; Janssen et al. 2005; Lau et al. 2005). Several studies are ongoing with the combination of Peg-IFN- $\alpha$ and ETV or TFV (Kao 2014), but, presently, this type of combination is not yet recommended. Furthermore, there are no data to indicate an advantage of de novo combination with ETV and TFV in NA-naïve patients, although more studies in patients with high baseline viremia (HBV DNA $>10^{8} \mathrm{IU} / \mathrm{mL}$ ) are required.

Current treatments for CHB based on NAs allow one to control viral replication and liver disease in the majority of patients (EASL 2012; Lampertico and Liaw 2012; Scaglione and Lok 2012; Buti 2014). However, because NAs are not able to clear cccDNA, lifelong therapies are required to maintain the antiviral effect. To define new therapeutic options and head toward treatments with finite duration, it is therefore necessary to develop new molecules acting on novel targets to set true combination therapies (Zoulim 2012). The persistence of $\mathrm{HBV}$ infection and the maintenance of the hepatocytes harboring cccDNA mainly result from a weak HBV-specific immune response. In this respect, strategies directly or indirectly targeting cccDNA, as well as the stimulation of the immune response against $\mathrm{HBV}$-infected cells, might represent a relevant approach. An efficient control of viral infections requires a concerted action of both innate and adaptive immune responses, as observed in the case of self-resolving HBV infection, which occurs in $~ 90 \%$ of "immune-competent adults" exposed to the virus (Bertoletti and Ferrari 2012). Restoring such responses in the chronic infection setting could help in reaching an immune control status similar to that observed in anti-HBs seroconverted patients or in "inactive carriers."

\section{Definitions of a "Cure" of HBV Infection}

There are several concepts around the definition of a "cure of HBV infection." The ultimate goal of treatment would be to eradicate viral cccDNA from the liver leading to a complete and definite clearance (i.e., "absolute cure") of infected hepatocytes, thereby preventing the risk of reactivation in case of a loss of immune control. However, it is worth noting that this would not abolish the consequences of viral genome integration in the host chromosomes of infected cells, as this event could occur early after the onset of infection (Seeger et al. 2014). On the other hand, in patients who spontaneously resolved viral infection with HBsAg clearance and anti-HBs (HBs antibody, i.e., HBsAb) seroconversion, cccDNA might not be completely eradicated, and the few persisting infected cells are supposed to be under the control of the host immune response. Therefore, a 
"clinical or functional cure" of infection could be defined by HBsAg clearance and HBsAb seroconversion, despite the lack of complete cccDNA eradication. The "functional cure" would be considered as long as the host immune response controls the infection and could be defined by the absence of relapse after treatment cessation. Another end point, which could be envisaged, is the control of infection, as observed in inactive carriers-defined by the persistence of low levels of serum HBsAg and HBV DNA levels with normal ALT levels - in which the HBV-specific immune response would be strong enough to keep viral replication under control, thereby allowing antiviral treatment cessation.

\section{Identification of Novel Drug Targets}

New drugs targeting novel targets are needed to develop true combination therapies and step toward a cure of HBV infection. Several targets and novel compounds are currently being evaluated in in vitro and in vivo experimental mod-
Antiviral Therapies of Chronic HBV Infections

els, which could potentially complement NA or IFN-based therapy (see Fig. 3).

The recent discovery of one cellular receptor for HBV entry, hNTCP (human sodium taurocholate cotransporting polypeptide, also known as SLC10A1), has provided extremely valuable information regarding the development of entry inhibitors (Yan et al. 2012; Urban et al. 2014). Previous to this discovery, it had been shown that myristoylated preS peptide (Myrcludex-B), a lipopeptide derived from the preS1 domain of the HBV envelope, could prevent $\mathrm{HBV}$ infection in hepatocyte culture as well as in vivo in humanized uPA/SCID mice, in which the liver is repopulated by human hepatocytes (Petersen et al. 2008). Using the same mouse model, it was also shown that treatment with this HBV entry inhibitor efficiently inhibited the establishment of hepatitis $\delta$ virus (HDV) infection, which requires $\mathrm{HBV}$ envelopes for its infectivity (Lutgehetmann et al. 2012). Then retrospectively, it was interesting to see that the inhibition of viral entry by the preS peptide was indeed the result of its interaction with

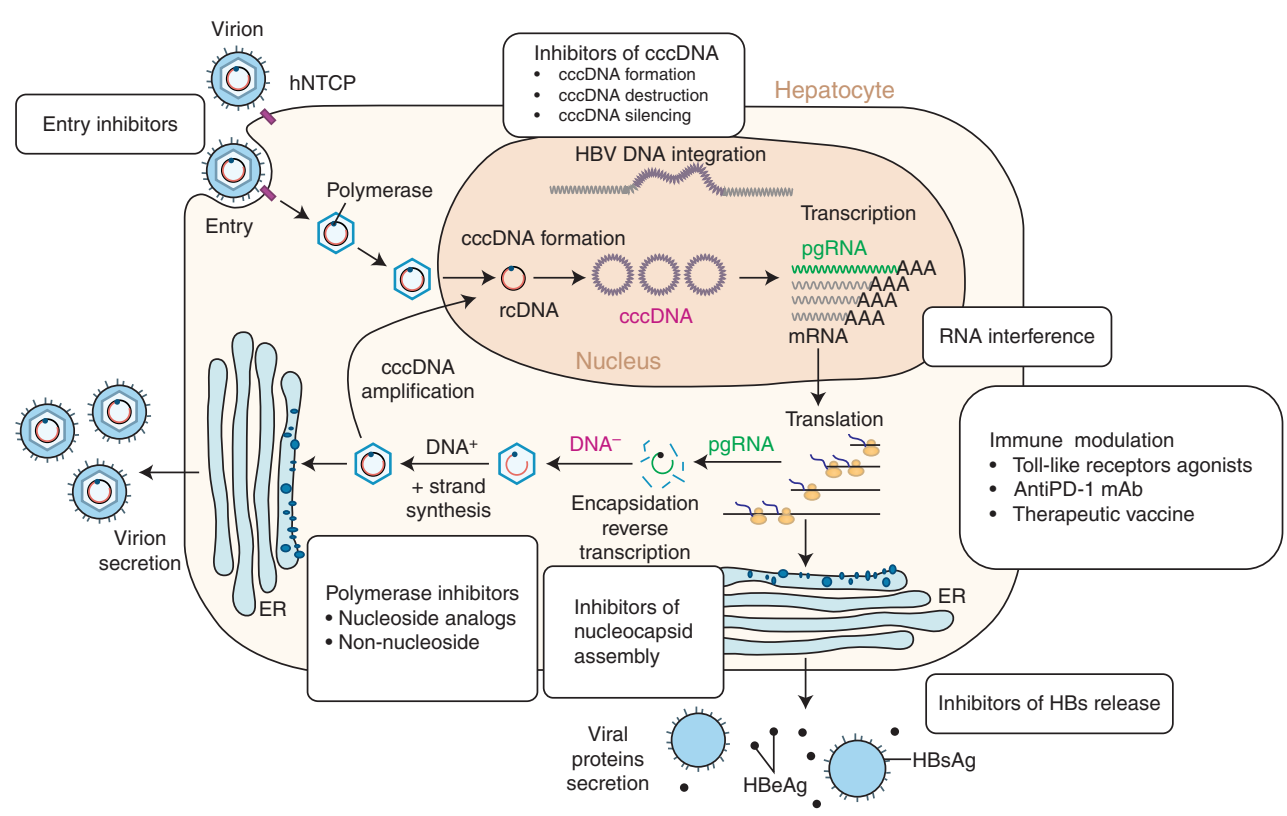

Figure 3. Schematic representation of various classes of anti-HBV molecules on the Hepatitis B virus (HBV) life cycle. Compounds in development for chronic hepatitis B can be seen at www.hepb.org/professionals/ hbf_drug_watch.htm. cccDNA, covalently closed circular DNA; ER, endoplasmic reticulum; hNTCP, human sodium taurocholate cotransporting polypeptide; pgRNA, pregenomic RNA; rcDNA; relaxed circular DNA. 
hNTCP (Ni et al. 2014). Furthermore, drugs that inhibit hNTCP function, such as cyclosporine, also decrease viral infectivity in cell-culture models (Nkongolo et al. 2014; Watashi et al. 2014). As hepatocyte turnover and reinfection cycles might be needed to maintain persistent infection, this could make a reasonable case for the evaluation of such an entry inhibitor in the context of chronic infections. The specific value of entry inhibitors in the treatment of $\mathrm{CHB}$ will need to be shown in clinical trials. Because there is currently no specific antiviral for HDV infection except IFN- $\alpha$, which provides sustained virologic response in only $25 \%$ of patients (Heidrich et al. 2014), the clinical evaluation of entry inhibitors in patients who are coinfected with $\mathrm{HBV}$ and HDV is also warranted.

The initial formation (and maintenance by recycling of nucleocapsid) of cccDNA, from relaxed circular DNA (rcDNA) genome nuclear delivery, represents a very important antiviral target (Zoulim et al. 2013b; Seeger et al. 2014). The cellular and biochemical events required for this process involve the transport of nucleocapsid to the nucleus, and the transformation of the rcDNA genome into cccDNA via the removal of the viral polymerase covalently linked to viral minus-strand DNA, the removal of the short RNA primer for plus-strand DNA synthesis, the completion of plus-strand DNA, and the removal of the viral minus-strand DNA redundancy (Zoulim et al. 2013b; Seeger et al. 2014). These steps seem to involve several nuclear enzymes, including TDP2 and endonucleases, for which it may be difficult to target a function specific to the viral life cycle (Sohn et al. 2009; Koniger et al. 2014). Administration of NAs failed to prevent the initial formation of cccDNA after de novo infection of hepatocytes in animal models of infection, whereas their long-term administration to already infected individuals seems to decrease the pool of already established cccDNA by the potential inhibition of the recycling of nucleocapsids containing viral genomes to the nucleus; but one cannot exclude that this might also be owing to the clearance of infected cells from the liver by programmed cell death or immune killing. Interestingly, it was recently reported that small molecules might specifically target cccDNA formation. Two structurally related disubstituted-sulfonamide compounds were identified and may potentially serve as proof-of-concept (POC) drug candidates to eliminate cccDNA from chronic HBV infection by preventing initial formation and/ or maintenance by nucleocapsid recycling, but not by degrading already formed cccDNA (Cai et al. 2012). On the other hand, it was recently shown that IFN- $\alpha$ and lymphotoxin- $\beta$ receptor activation up-regulated APOBEC $3 \mathrm{~A}$ and APO$\mathrm{BEC} 3 \mathrm{~B}$ cytidine deaminases, respectively, and induced nonhepatotoxic degradation of nuclear hepatitis $B$ virus cccDNA. Interestingly, $\mathrm{HBc}$ could mediate APOBEC3A/B interaction with nuclear cccDNA, resulting in cytidine deamination, apurinic/apyrimidinic site formation, and finally cccDNA degradation that prevented HBV reactivation (Lucifora et al. 2014). This opens new avenues to achieve cccDNA degradation by novel strategies. In this respect, the use of cccDNA-specific meganuclease (or related sequence-specific homing endonucleases) delivered to infected cells by gene therapy could also be an interesting approach to degrade cccDNA. Because the degradation of cccDNA from all cells remains a difficult goal to reach, the transcriptional silencing of cccDNA activity represents a step forward in developing original strategies. A first POC approach consisted in the expression of zinc-finger proteins able to bind the duck hepatitis $B$ virus regulatory genetic sequence (enhancer), in infected cells. After cotransfection of vectors encoding these proteins and DHBV in cultured cells, it was shown that zinc-finger proteins are able to bind to the DHBV enhancer and interfere with viral transcription, resulting in decreased production of viral products and progeny virus genomes (Zimmerman et al. 2008). Yet the delivery of such targeted proteins to infected hepatocytes in vivo remains a challenge. Interfering with cccDNA-associated chromatin proteins is another exciting approach. Indeed, the acetylation and/or methylation status of the histones bound to cccDNA affect its transcriptional activity. It was shown in cell-culture and in humanized mice that IFN administration induces cccDNA-bound histone hypoacetylation, 
as well as active recruitment to the cccDNA of transcriptional corepressors (Belloni et al. 2012). IFN- $\alpha$ treatment also reduced binding of the STAT1 and STAT2 transcription factors to active cccDNA. This may represent a molecular mechanism whereby IFN- $\alpha$ mediates epigenetic repression of cccDNA transcriptional activity, which may assist in the development of novel therapeutics. In this respect, the research aiming at developing epigenome-modifying enzyme inhibitors for cancer indications (Bojang and Ramos 2014; Jones 2014), has to be scrutinized to potentially apply this knowledge to $\mathrm{CHB}$ treatment.

Beside the polymerase protein, HBV does not encode for other proteins bearing enzymatic activities, thus rendering difficult the development of other direct acting agents (DAA), as successfully shown for in the HCV field (Welsch et al. 2012). Yet other HBV protein functions could be targeted. In this respect, $\mathrm{HBx}$ protein represents an interesting theoretical target. Indeed, it was shown that this protein is required for viral infection in vivo (Zoulim et al. 1994; Seeger et al. 2014). More recently, it was shown in primary hepatocyte cultures, as well as HepaRG cells (Gripon et al. 2002), that the HBx protein is necessary to initiate and maintain viral replication via cccDNA transcriptional regulation (Lucifora et al. 2011). This may be consistent with the observation that nuclear HBx binds the HBV minichromosome and modifies the epigenetic regulation of cccDNA function (Belloni et al. 2009). HBx has also been shown to interact with DDB1, an adaptor protein, which on binding to CUL4 proteins, forms cullin-RING ligase complexes involved in major cellular functions (i.e., DNA repair, DNA transcription, DNA replication, etc.) (Angers et al. 2006). This interaction would prevent HBx degradation (i.e., favor HBx stabilization), and also induce the degradation of host factors, which could have antiviral functions, with both actions contributing to better HBV replication. The domain of interaction between $\mathrm{HBx}$ and DDB1 has been mapped ( $\mathrm{Li}$ et al. 2010), and could serve to design molecules interfering with this protein-protein interaction and leading to an antiviral phenotype. A more detailed knowledge of HBx function should help to target this key regulator of viral replication.

Several attempts have been made to develop inhibitors of nucleocapsid assembly or stability. A few non-nucleosidic molecules, belonging to the family of phenylpropenamides (AT-61 and AT-130) and heteroaryldihydropyrimidines (BAY41-4109) (Delaney et al. 2002; Deres et al. 2003), could prevent RNA encapsidation or destabilize nucleocapsids, respectively. These antiviral compounds were shown to inhibit the replication of wild-type $\mathrm{HBV}$ as well as $\mathrm{HBV}$ mutants resistant to NAs (Billioud et al. 2011). Their molecular mechanism of action is to bind to $\mathrm{HBc}$, and either induce its misdirection or speed up its multimerization in a way that pregenomic RNA (pgRNA) is not incorporated anymore (Zlotnick and Mukhopadhyay 2011). Besides their effect on viral DNA synthesis and virion production, these agents may potentially inhibit the intracellular amplification of cccDNA via the inhibition of nucleocapsid recycling to the nucleus, and may have other beneficial effects by modulating interactions between HBV and its hosts, for which the exact mechanisms need to be unraveled. For instance, results of recent studies suggest that $\mathrm{HBV}$ core may activate the transcriptional activity of viral cccDNA and repress the transcription of some ISGs (Belloni et al. 2013; Gruffaz et al. 2013). Targeting these specific viral functions may result in mutual beneficial antiviral effects.

A more general manner to inhibit HBV protein functions would be to prevent their translation by degrading viral RNAs. In this respect, the use of antisense or small interfering RNAs (siRNAs) could represent a POC approach to show that inhibiting the expression of viral proteins in the first place could inhibit viral replication or restore functions otherwise inhibited by viral protein (Wooddell et al. 2013). Hence, one could inhibit the production of $\mathrm{HBx}, \mathrm{HBc}$, as well as viral secreted protein ( $\mathrm{HBeAg}$ and HBsAg, which may have immunomodulatory functions and contribute to HBV immune escape [Bertoletti and Ferrari 2012]) and obtain multiple antiviral effects. But using siRNAs in vivo and delivering them to the entire liver to target all infected cells remains a therapeutic 
challenge, although major progress has recently been made in that area.

Interfering with other steps of viral morphogenesis and virion infectivity through the modulation of viral envelope glycosylation by $\alpha$-glucosidase inhibitors represent other relevant approaches to be developed (Block et al. 1998; Lazar et al. 2007). Other groups have also tried to use triazolopyrimidine derivatives to decrease viral envelope protein secretion in experimental models in the perspective of restoring specific immune responses against viral envelope epitopes (Yu et al. 2011).

Besides the inhibition of viral replication, other antiviral strategies consist in the boosting of specific immune responses against HBV. Based on recent knowledge of the role of innate responses in the control of HBV infection (Zoulim et al. 2013a), several approaches have been evaluated to determine, among others, the effect of TLR2 or TLR7 stimulation in the woodchuck and chimpanzee models, respectively. For instance, it was shown that a TLR7 agonist can induce IFN- $\alpha$ and ISG expression in chimpanzees, which was associated with reduced serum and liver viral load (Lanford et al. 2013). Transient elevations of serum transaminase levels were observed. The data were consistent with immune elimination of infected hepatocytes. Another recent study showed that ETV administration can restore TLR2 expression in infected cells, and that administration of TLR2 ligands inhibited viral replication (Zhang et al. 2012). It would be interesting to test whether the combination of NA with a TLR2 or TLR7 agonist results in an enhanced antiviral effect (Durantel and Zoulim 2012). Targeting viral determinants, which are responsible for defective innate immune responses, could specifically restore innate immunity that would be restricted to infected cells and not to all cells expressing innate sensors.

In chronic HBV infection, defective T-cell function is probably maintained by the effect of the prolonged exposure of $\mathrm{T}$ cells to large quantities of viral antigens and by the tolerogenic features of both liver cells and liver resident cells (Bertoletti and Ferrari 2012; Knolle and Thimme 2014). These two combined mechanisms can result in the deletion of HBVspecific T cells or in their functional inactivation (exhaustion), which is characterized by an increased expression of negative costimulatory molecules and dysregulation of costimulatory pathways, which affect antiviral T-cell responses. In principle, restoration of immune control could follow different strategies (Bertoletti and Ferrari 2012; Knolle and Thimme 2014). The inhibition of viral replication and decline in HBV antigens could lead to partial restoration of antiviral HBV-specific T-cell functions and inhibition of HBV suppressive effects (Boni et al. 2012). Blockade of negative regulatory pathways could be effective, by partially restoring $\mathrm{HBV}$-specific T-cell functions (Kosinska et al. 2013). Antiapoptotic drugs may reduce HBVspecific T-cell apoptosis and fight against $\mathrm{T}$ cell exhaustion. The de novo reconstitution of functionally active HBV-specific T cells or activation of heterologous $\mathrm{T}$ cells is also another potential strategy. Besides these targeted immune strategies, attempts to deliver therapeutic vaccines (with recombinant proteins, specific peptides, DNAvaccine, or DNA delivered by viral vectors) have been evaluated in chronically infected patients or animals (Kosinska et al. 2013), and may represent an interesting treatment option to be further evaluated in association with NAs, at least in selected patient populations; these different studies have been reviewed recently (Michel et al. 2011).

These new strategies should be evaluated in the most relevant experimental models. Infectious cell-culture models for HBV rely on primary human hepatocyte culture and the HepaRG cell line (Gripon et al. 1988, 2002), which are the only robust models used to study the entire HBV life cycle, but are still tedious to work with, compared with the traditional HepG2 or Huh7 hepatoma cell lines, which are used to study the late stages of HBV replication after transfection of replication-competent constructs. These cell-culture models are now improved with the reconstitution of hNTCP expression allowing viral infection and the study of critical steps just as cccDNA formation (Yan et al. 2012; Urban et al. 2014). Because access to chimpanzees is restricted, human HBV replica- 
tion is currently studied in vivo in humanized uPA/SCID mice (Petersen et al. 2008). However, these mouse models have the disadvantage of using an immune-deficient host. Nevertheless, these experimental models should be useful for validating new targets and elucidating the mode of action of new antiviral compounds. Improvement of these models is now in progress with genetic engineering of mouse lineage to express hNTPC, as well as to engineer doubly humanized mice for both human hepatocytes and the human immune system. The development of more robust cell culture models and small primate models to recapitulate $\mathrm{HBV}$ infection and its pathogenesis is also highly desirable (Dupinay et al. 2013; Shlomai et al. 2014).

\section{CONCLUSION}

The field of anti-HBV therapy is entering a new era with a renewed interest of the scientific, medical, and industrial communities to develop new treatment concepts toward a cure of $\mathrm{HBV}$ infection. The better knowledge of the viral life cycle and its interaction with the liver microenvironment and host immune responses, together with the development of new study models will provide the right momentum for upfront research in this area. The better understanding and measurement of the major clinical end points also provide better guidance for the preclinical and early clinical evaluation of treatment concepts, which should translate into improved treatment outcomes in the future.

\section{REFERENCES}

Angers S, Li T, Yi X, MacCoss MJ, Moon RT, Zheng N. 2006. Molecular architecture and assembly of the DDB1CUL4A ubiquitin ligase machinery. Nature 443: 590593.

Belloni L, Pollicino T, De Nicola F, Guerrieri F, Raffa G, Fanciulli M, Raimondo G, Levrero M. 2009. Nuclear HBx binds the HBV minichromosome and modifies the epigenetic regulation of cccDNA function. Proc Natl Acad Sci 106: 19975-19979.

Belloni L, Allweiss L, Guerrieri F, Pediconi N, Volz T, Pollicino T, Petersen J, Raimondo G, Dandri M, Levrero M. 2012. IFN- $\alpha$ inhibits HBV transcription and replication in cell culture and in humanized mice by targeting the epigenetic regulation of the nuclear cccDNA minichromosome. J Clin Invest 122: 529-537.
Belloni L, Li LC, Palumbo GA, Chirapu SR, Calvo L, Finn M, Lopatin U, Zlotnick A, Levrero M. 2013. HAPs hepatitis B virus (HBV) capsid inhibitors block core protein interaction with the viral minichromosome and host cell genes and affect cccDNA transcription and stability. Hepatology 58: 277A.

Berg T, Zoulim F, Moeller B, Trinh H, Marcellin P, Chan S, Kitrinos KM, Dinh P, Flaherty JF Jr, McHutchison JG, et al. 2014. Long-term efficacy and safety of emtricitabine plus tenofovir DF vs. tenofovir DF monotherapy in adefovir-experienced chronic hepatitis B patients. J Hepatol 60: 715-722.

Bertoletti A, Ferrari C. 2012. Innate and adaptive immune responses in chronic hepatitis B virus infections: Towards restoration of immune control of viral infection. Gut 61: $1754-1764$.

Billioud G, Pichoud C, Puerstinger G, Neyts J, Zoulim F. 2011. The main hepatitis B virus (HBV) mutants resistant to nucleoside analogs are susceptible in vitro to nonnucleoside inhibitors of HBV replication. Antiviral Res 92: $271-276$.

Block TM, Lu X, Mehta AS, Blumberg BS, Tennant B, Ebling M, Korba B, Lansky DM, Jacob GS, Dwek RA. 1998. Treatment of chronic hepadnavirus infection in a woodchuck animal model with an inhibitor of protein folding and trafficking. Nat Med 4: 610-614.

Bojang P Jr, Ramos KS. 2014. The promise and failures of epigenetic therapies for cancer treatment. Cancer Treat Rev 40: 153-169.

Boni C, Laccabue D, Lampertico P, Giuberti T, Viganò M, Schivazappa S, Alfieri A, Pesci M, Gaeta GB, Brancaccio $\mathrm{G}$, et al. 2012. Restored function of HBV-specific T cells after long-term effective therapy with nucleos(t)ide analogues. Gastroenterology 143: 963-973.e9.

Buti M. 2014. HBeAg-positive chronic hepatitis B: Why do I treat my patients with nucleos(t)ide analogs? Liver Int 34: $108-111$.

Cai D, Mills C, Yu W, Yan R, Aldrich CE, Saputelli JR, Mason WS, Xu X, Guo JT, Block TM, et al. 2012. Identification of the disubstituted sulfonamide compounds as specific inhibitors of hepatitis B virus covalently closed circular DNA formation. Antimicrob Agents Chemother 56: 42774288.

Carrouee-Durantel S, Durantel D, Werle-Lapostolle B, Pichoud C, Naesens L, Neyts J, Trepo C, Zoulim F. 2008. Suboptimal response to adefovir dipivoxil therapy for chronic hepatitis B in nucleoside-naïve patients is not due to pre-existing drug-resistant mutants. Antivir Ther 13: $381-388$.

Chan HL, Chan CK, Hui AJ, Chan S, Poordad F, Chang TT, Mathurin P, Flaherty JF, Lin L, Corsa A, et al. 2014. Effects of tenofovir disoproxil fumarate in hepatitis $\mathrm{B}$ e antigenpositive patients with normal levels of alanine aminotransferase and high levels of hepatitis B virus DNA. Gastroenterology 146: 1240-1248.

Chang TT, Gish RG, de Man R, Gadano A, Sollano J, Chao YC, Lok AS, Han KH, Goodman Z, Zhu J. et al. 2006. A comparison of entecavir and lamivudine for $\mathrm{HBeAg}$-positive chronic hepatitis B. N Engl J Med 354: 1001-1010.

Cho J-Y, Paik Y-H, Sohn W, Cho HC, Gwak G-Y, Choi MS, Lee JH, Koh KC, Paik SW, Yoo BC. 2014. Patients with chronic hepatitis B treated with oral antiviral therapy 
retain a higher risk for HCC compared with patients with inactive stage disease. Gut 63: 1943-1950.

Delaney WE, Edwards R, Colledge D, Shaw T, Furman P, Painter G, Locarnini S. 2002. Phenylpropenamide derivatives AT-61 and AT-130 inhibit replication of wild-type and lamivudine-resistant strains of hepatitis B virus in vitro. Antimicrob Agents Chemother 46: 3057-3060.

Deres K, Schroder CH, Paessens A, Goldmann S, Hacker HJ, Weber O, Kramer T, Niewohner U, Pleiss U, Stoltefuss J, et al. 2003. Inhibition of hepatitis B virus replication by drug-induced depletion of nucleocapsids. Science 299: 893-896.

Dienstag JL, Goldin RD, Heathcote EJ, Hann HW, Woessner M, Stephenson SL, Gardner S, Gray DF, Schiff ER. 2003. Histological outcome during long-term lamivudine therapy. Gastroenterology 124: 105-117.

Dupinay T, Gheit T, Roques P, Cova L, Chevallier-Queyron P, Tasahsu SI, Le Grand R, Simon F, Cordier G, Wakrim L, et al. 2013. Discovery of naturally occurring transmissible chronic hepatitis B virus infection among Macaca fascicularis from Mauritius Island. Hepatology 58: 1610 1620.

Durantel D, Zoulim F. 2012. Interplay between hepatitis B virus and TLR2-mediated innate immune responses: Can restoration of TLR2 functions be a new therapeutic option? J Hepatol 57: 486-489.

Durantel D, Brunelle M-N, Gros E, Carrouée-Durantel S, Pichoud C, Villet S, Trepo C, Zoulim F. 2005. Resistance of human hepatitis B virus to reverse transcriptase inhibitors: From genotypic to phenotypic testing. J Clin Virol 34: $\mathrm{S} 34-\mathrm{S} 43$.

EASL. 2012. EASL clinical practice guidelines: Management of chronic hepatitis B virus infection. J Hepatol 57: $167-$ 185.

Fung SK, Andreone P, Han SH, Rajender Reddy K, Regev A, Keeffe EB, Hussain M, Cursaro C, Richtmyer P, Marrero JA, et al. 2005. Adefovir-resistant hepatitis B can be associated with viral rebound and hepatic decompensation. J Hepatol 43: 937-943.

Fung S, Kwan P, Fabri M, Horban A, Pelemis M, Hann H-W, Gurel S, Caruntu FA, Flaherty JF, Massetto B, et al. 2014. Randomized comparison of tenofovir disoproxil fumarate vs emtricitabine and tenofovir disoproxil fumarate in patients with lamivudine-resistant chronic hepatitis B. Gastroenterology 146: 980-988.

Gane EJ, Deray G, Liaw Y-F, Lim SG, Lai C-L, Rasenack J, Wang Y, Papatheodoridis G, Di Bisceglie A, Buti M, et al. 2014. Telbivudine improves renal function in patients with chronic hepatitis B. Gastroenterology 146: 138146.e5.

Gish RG, Lok AS, Chang TT, de Man RA, Gadano A, Sollano J, Han KH, Chao YC, Lee SD, Harris M, et al. 2007. Entecavir therapy for up to 96 weeks in patients with $\mathrm{HBeAg}$-positive chronic hepatitis B. Gastroenterology 133: 1437-1444.

Gish R, Jia JD, Locarnini S, Zoulim F. 2012. Selection of chronic hepatitis B therapy with high barrier to resistance. Lancet Infect Dis 12: 341-353.

Gordon SC, Krastev Z, Horban A, Petersen J, Sperl J, Dinh P, Martins EB, Yee LJ, Flaherty JF, Kitrinos KM, et al. 2013. Efficacy of tenofovir disoproxil fumarate at 240 weeks in patients with chronic hepatitis B with high baseline viral load. Hepatology 58: 505-513.

Gripon P, Diot C, Theze N, Fourel I, Loreal O, Brechot C, Guguen-Guillouzo C. 1988. Hepatitis B virus infection of adult human hepatocytes cultured in the presence of dimethyl sulfoxide. J Virol 62: 4136-4143.

Gripon P, Rumin S, Urban S, Le Seyec J, Glaise D, Cannie I, Guyomard C, Lucas J, Trepo C, Guguen-Guillouzo C. 2002. Infection of a human hepatoma cell line by hepatitis B virus. Proc Natl Acad Sci 99: 15655-15660.

Gruffaz M, Testoni B, Luangsay S, Fusil F, Malika AG, Mancip J, Petit MA, Javanbakht H, Cosset FL, Zoulim F, et al. 2013. The nuclear function of hepatitis B capsid (HBc) protein is to inhibit IFN response very early after infection of hepatocytes. Hepatology 58: 276A.

Hadziyannis SJ, Tassopoulos NC, Heathcote EJ, Chang TT, Kitis G, Rizzetto M, Marcellin P, Lim SG, Goodman Z, $\mathrm{Ma}$ J, et al. 2006. Long-term therapy with adefovir dipivoxil for HBeAg-negative chronic hepatitis B for up to 5 years. Gastroenterology 131: 1743-1751.

Heathcote EJ, Marcellin P, Buti M, Gane E, De Man RA, Krastev Z, Germanidis G, Lee SS, Flisiak R, Kaita K, et al. 2011. Three-year efficacy and safety of tenofovir disoproxil fumarate treatment for chronic hepatitis B. Gastroenterology 140: 132-143.

Heidrich B, Yurdaydin C, Kabacam G, Ratsch BA, Zachou K, Bremer B, Dalekos GN, Erhardt A, Tabak F, Yalcin K, et al. 2014. Late HDV RNA relapse after peginterferon $\alpha$-based therapy of chronic hepatitis delta. Hepatology 60: 87-97.

Hosaka T, Suzuki F, Kobayashi M, Seko Y, Kawamura Y, Sezaki H, Akuta N, Suzuki Y, Saitoh S, Arase Y, et al. 2013. Long-term entecavir treatment reduces hepatocellular carcinoma incidence in patients with hepatitis B virus infection. Hepatology 58: 98-107.

Janssen HLA, van Zonneveld M, Senturk H, Zeuzem S, Akarca US, Cakaloglu Y, Simon C, So TMK, Gerken G, de Man RA, et al. 2005. Pegylated interferon alfa-2b alone or in combination with lamivudine for HBeAg-positive chronic hepatitis B: A randomised trial. Lancet 365: 123 129.

Jones PA. 2014. At the tipping point for epigenetic therapies in cancer. J Clin Invest 124: 14-16.

Jordheim LP, Durantel D, Zoulim F, Dumontet C. 2013. Advances in the development of nucleoside and nucleotide analogues for cancer and viral diseases. Nat Rev Drug Discov 12: 447-464.

Kao JH. 2014. HBeAg-positive chronic hepatitis B: Why do I treat my patients with pegylated interferon? Liver Int 34: $112-119$.

Kennedy PT, Sandalova E, Jo J, Gill U, Ushiro-Lumb I, Tan AT, Naik S, Foster GR, Bertoletti A. 2012. Preserved T-cell function in children and young adults with immune-tolerant chronic hepatitis B. Gastroenterology 143: 637-645.

Kitrinos KM, Corsa A, Liu Y, Flaherty J, Snow-Lampart A, Marcellin P, Borroto-Esoda K, Miller MD. 2014. No detectable resistance to tenofovir disoproxil fumarate after 6 years of therapy in patients with chronic hepatitis B. Hepatology 59: 434-442.

Knolle PA, Thimme R. 2014. Hepatic immune regulation and its involvement in viral hepatitis infection. Gastroenterology 146: 1193-1207. 
Koniger C, Wingert I, Marsmann M, Rosler C, Beck J, Nassal M. 2014. Involvement of the host DNA-repair enzyme TDP2 in formation of the covalently closed circular DNA persistence reservoir of hepatitis B viruses. Proc Natl Acad Sci 111: E4244-E4253.

Kosinska AD, Zhang E, Johrden L, Liu J, Seiz PL, Zhang X, Ma Z, Kemper T, Fiedler M, Glebe D, et al. 2013. Combination of DNA prime-Adenovirus boost immunization with entecavir elicits sustained control of chronic hepatitis B in the woodchuck model. PloS Pathog 9: e1003391.

Lai CL, Yuen MF. 2013. Prevention of hepatitis B virus-related hepatocellular carcinoma with antiviral therapy. Hepatology 57: 399-408.

Lai CL, Shouval D, Lok AS, Chang TT, Cheinquer H, Goodman Z, DeHertogh D, Wilber R, Zink RC, Cross A, et al. 2006. Entecavir versus lamivudine for patients with HBeAg-negative chronic hepatitis B. N Engl J Med 354: $1011-1020$

Lai M, Hyatt BJ, Nasser I, Curry M, Afdhal NH. 2007. The clinical significance of persistently normal ALT in chronic hepatitis B infection. J Hepatol 47: 760-767.

Lampertico P, Liaw YF. 2012. New perspectives in the therapy of chronic hepatitis B. Gut 61: 18-24.

Lanford RE, Guerra B, Chavez D, Giavedoni L, Hodara VL, Brasky KM, Fosdick A, Frey CR, Zheng J, Wolfgang G, et al. 2013. GS-9620, an oral agonist of toll-like receptor7 , induces prolonged suppression of hepatitis B virus in chronically infected chimpanzees. Gastroenterology 144: $1508-1517$.

Lau GKK, Piratvisuth T, Luo KX, Marcellin P, Thongsawat S, Cooksley G, Gane E, Fried MW, Chow WC, Paik SW, et al. 2005. Peginterferon alfa-2a, lamivudine, and the combination for HBeAg-positive chronic hepatitis B. $N$ Engl J Med 352: 2682-2695.

Lavocat F, Deny P, Pichoud C, Al Hawajri N, Kitrinos K, Borroto-Esoda K, Zoulim F. 2013. Similar evolution of hepatitis B virus quasispecies in patients with incomplete adefovir response receiving tenofovir/emtricitabine combination or tenofovir monotherapy. J Hepatol 59: 684-695.

Lazar C, Durantel D, Macovei A, Zitzmann N, Zoulim F, Dwek RA, Branza-Nichita N. 2007. Treatment of hepatitis $\mathrm{B}$ virus-infected cells with $\alpha$-glucosidase inhibitors results in production of virions with altered molecular composition and infectivity. Antiviral Res 76: 30-37.

Le Guerhier F, Pichoud C, Guerret S, Chevallier M, Jamard C, Hantz O, Li XY, Chen SH, King I, Trepo C, et al. 2000. Characterization of the antiviral effect of $2^{\prime}, 3^{\prime}$-dideoxy$2^{\prime}, 3^{\prime}$-didehydro- $\beta$-L-5-fluorocytidine in the duck hepatitis B virus infection model. Antimicrob Agents Chemother 44: 111-122.

Le Guerhier F, Pichoud C, Jamard C, Guerret S, Chevallier M, Peyrol S, Hantz O, King I, Trepo C, Cheng YC, et al. 2001. Antiviral activity of $\beta$-L- $2^{\prime}, 3^{\prime}$-dideoxy- $2^{\prime}, 3^{\prime}$-didehydro-5-fluorocytidine in woodchucks chronically infected with woodchuck hepatitis virus. Antimicrob Agents Chemother 45: 1065-1077.

Li T, Robert EI, van Breugel PC, Strubin M, Zheng N. 2010 A promiscuous $\alpha$-helical motif anchors viral hijackers and substrate receptors to the CUL4-DDB1 ubiquitin ligase machinery. Nat Struct Mol Biol 17: 105-111.
Antiviral Therapies of Chronic HBV Infections

Liaw YF, Sung JJ, Chow WC, Farrell G, Lee CZ, Yuen H, Tanwandee T, Tao QM, Shue K, Keene ON, et al. 2004. Lamivudine for patients with chronic hepatitis B and advanced liver disease. N Engl J Med 351: 1521-1531.

Liaw YF, Raptopoulou-Gigi M, Cheinquer H, Sarin SK, Tanwandee T, Leung N, Peng CY, Myers RP, Brown RS Jr, Jeffers L, et al. 2011a. Efficacy and safety of entecavir versus adefovir in chronic hepatitis B patients with hepatic decompensation: A randomized open-label study. Hepatology 54: 91-100.

Liaw YF, Sheen IS, Lee CM, Akarca US, Papatheodoridis GV, Suet-Hing Wong F, Chang TT, Horban A, Wang C, Kwan P, et al. 2011b. Tenofovir disoproxil fumarate (TDF), emtricitabine/TDF, and entecavir in patients with decompensated chronic hepatitis B liver disease. Hepatology 53: $62-72$.

Liu Y, Kitrinos KM. 2013. In vitro phenotyping of recombinant hepatitis B virus containing the polymerase/ reverse transcriptase gene from clinical isolates. Methods Mol Biol 1030: 163-181.

Liu Y, Wang C, Zhong Y, Chen L, Li X, Ji D, Wang H, Xin S, Zoulim F, Xu D. 2010. Evolution and suppression of HBV strains with multidrug resistance to lamivudine, adefovir dipivoxil and entecavir in a patient with chronic hepatitis B. Antivir Ther 15: 1185-1190.

Lok AS, Lai CL, Leung N, Yao GB, Cui ZY, Schiff ER, Dienstag JL, Heathcote EJ, Little NR, Griffiths DA, et al. 2003. Long-term safety of lamivudine treatment in patients with chronic hepatitis B. Gastroenterology 125: 17141722

Lok AS, Trinh H, Carosi G, Akarca US, Gadano A, Habersetzer F, Sievert W, Wong D, Lovegren M, Cohen D, et al. 2012. Efficacy of entecavir with or without tenofovir disoproxil fumarate for nucleos $(t)$ ide-naïve patients with chronic hepatitis B. Gastroenterology 143: 619628.e1.

Lucifora J, Arzberger S, Durantel D, Belloni L, Strubin M, Levrero M, Zoulim F, Hantz O, Protzer U. 2011 Hepatitis B virus $\mathrm{X}$ protein is essential to initiate and maintain virus replication after infection. J Hepatol 55: 996-1003.

Lucifora J, Xia Y, Reisinger F, Zhang K, Stadler D, Cheng X, Sprinzl MF, Koppensteiner H, Makowska Z, Volz T, et al. 2014. Specific and nonhepatotoxic degradation of nuclear hepatitis B virus cccDNA. Science 343: 1221-1228.

Lutgehetmann M, Mancke LV, Volz T, Helbig M, Allweiss L, Bornscheuer T, Pollok JM, Lohse AW, Petersen J, Urban S, et al. 2012. Humanized chimeric uPA mouse model for the study of hepatitis B and D virus interactions and preclinical drug evaluation. Hepatology 55: 685-694.

Marcellin P, Lau GKK, Bonino F, Farci P, Hadziyannis S, Jin R, Lu Z-M, Piratvisuth T, Germanidis G, Yurdaydin C, et al. 2004. Peginterferon alfa-2a alone, lamivudine alone, and the two in combination in patients with hbeag-negative chronic hepatitis B. N Engl J Med 351: 1206-1217.

Marcellin P, Heathcote EJ, Buti M, Gane E, de Man RA, Krastev Z, Germanidis G, Lee SS, Flisiak R, Kaita K, et al. 2008. Tenofovir disoproxil fumarate versus adefovir dipivoxil for chronic hepatitis B. N Engl J Med 359: 2442 2455. 
Mason WS, Litwin S, Jilbert AR. 2008. Immune selection during chronic hepadnavirus infection. Hepatol Int 2: $3-16$.

Maynard M, Parvaz P, Durantel S, Chevallier M, Chevallier P, Lot M, Trepo C, Zoulim F. 2005. Sustained HBs seroconversion during lamivudine and adefovir dipivoxil combination therapy for lamivudine failure. $J$ Hepatol 42: $279-281$.

Micco L, Peppa D, Loggi E, Schurich A, Jefferson L, Cursaro C, Panno AM, Bernardi M, Brander C, Bihl F, et al. 2013 Differential boosting of innate and adaptive antiviral responses during pegylated-interferon- $\alpha$ therapy of chronic hepatitis B. J Hepatol 58: 225-233.

Michel ML, Deng Q, Mancini-Bourgine M. 2011. Therapeutic vaccines and immune-based therapies for the treatment of chronic hepatitis B: Perspectives and challenges. J Hepatol 54: 1286-1296.

Moraleda G, Saputelli J, Aldrich CE, Averett D, Condreay L, Mason WS. 1997. Lack of effect of antiviral therapy in nondividing hepatocyte cultures on the closed circular DNA of woodchuck hepatitis virus. J Virol 71: 9392 9399.

Ni Y, Lempp FA, Mehrle S, Nkongolo S, Kaufman C, Falth M, Stindt J, Koniger C, Nassal M, Kubitz R, et al. 2014 Hepatitis B and D viruses exploit sodium taurocholate co-transporting polypeptide for species-specific entry into hepatocytes. Gastroenterology 146: 1070-1083.

Nkongolo S, Ni Y, Lempp FA, Kaufman C, Lindner T, EsserNobis K, Lohmann V, Mier W, Mehrle S, Urban S. 2014. Cyclosporin A inhibits hepatitis B and hepatitis D virus entry by cyclophilin-independent interference with the NTCP receptor. J Hepatol 60: 723-731.

Ono A, Suzuki F, Kawamura Y, Sezaki H, Hosaka T, Akuta N, Kobayashi M, Suzuki Y, Saitou S, Arase Y, et al. 2012. Long-term continuous entecavir therapy in nucleos (t)ide-naïve chronic hepatitis B patients. J Hepatol 57: 508-514.

Papatheodoridis GV, Manolakopoulos S, Touloumi G, Vourli G, Raptoppoulou-Gigi M, Vasiladis T, Mimidis K, Gogos C, Ketikoglou I, Manesis EK, et al. 2011. Virological suppression does not prevent the development of hepatocellular carcinoma in HBeAg-negative chronic hepatitis B patients with cirrhosis receiving oral antivi$\mathrm{ral}(\mathrm{s})$ starting with lamivudine monotherapy: Results of the nationwide HEPNET. Greece cohort study. Gut 60: 1109-1116.

Patterson SJ, George J, Strasser SI, Lee AU, Sievert W, Nicoll AJ, Desmond PV, Roberts SK, Locarnini S, Bowden S, et al. 2011. Tenofovir disoproxil fumarate rescue therapy following failure of both lamivudine and adefovir dipivoxil in chronic hepatitis B. Gut 60: 247-254.

Petersen J, Dandri M, Mier W, Lutgehetmann M, Volz T, von Weizsacker F, Haberkorn U, Fischer L, Pollok JM, Erbes B, et al. 2008. Prevention of hepatitis B virus infection in vivo by entry inhibitors derived from the large envelope protein. Nat Biotechnol 26: 335-341.

Sadler AJ, Williams BRG. 2008. Interferon-inducible antiviral effectors. Nat Rev Immunol 8: 559-568.

Samuel CE. 2001. Antiviral actions of interferons. Clin Microbiol Rev 14: 778-809.
Scaglione SJ, Lok AS. 2012. Effectiveness of hepatitis B treatment in clinical practice. Gastroenterology 142: 13601368.e1.

Seeger C, Zoulim F, Mason WS. 2014. Hepadnaviruses. In Field's virology (ed. Knipe DM, Howley PM), p. 2185. Lippincott Williams \& Wilkins, Philadelphia.

Shlomai A, Schwartz RE, Ramanan V, Bhattaa de Jongyp YP, Bhatiasn YP, Rice CM. 2014. Modeling host interactions with hepatitis B virus using primary and induced pluripotent stem cell-derived hepatocellular systems. Proc Natl Acad Sci 111: 12193-12198.

Sogni P, Carrieri MP, Fontaine H, Mallet V, Vallet-Pichard A, Trabut JB, Meritet JF, Pol S. 2012. The role of adherence in virological suppression in patients receiving anti-HBV analogues. Antivir Ther 17: 395-400.

Sohn JA, Litwin S, Seeger C. 2009. Mechanism for CCC DNA synthesis in hepadnaviruses. PLoS ONE 4: e8093.

Sun J, Xie Q, Tan D, Ning Q, Niu J, Bai X, Fan R, Chen S, Cheng J, Yu Y, et al. 2014. The 104-week efficacy and safety of telbivudine-based optimization strategy in chronic hepatitis B patients: A randomized, controlled study. Hepatology 59: 1283-1292.

Thimme R, Dandri M. 2013. Dissecting the divergent effects of interferon- $\alpha$ on immune cells: Time to rethink combination therapy in chronic hepatitis B? J Hepatol 58: 205-209.

Urban S, Bartenschlager R, Kubitz R, Zoulim F. 2014. Strategies to inhibit entry of HBV and HDV into hepatocytes. Gastroenterology 147: 48-64.

Vigano M, Mangia G, Lampertico P. 2014. HBeAg-negative chronic hepatitis B: Why do I treat my patients with nucleos(t)ide analogues? Liver Int 34: 120-126.

Villet S, Ollivet A, Pichoud C, Barraud L, Villeneuve JP, Trepo C, Zoulim F. 2007. Stepwise process for the development of entecavir resistance in a chronic hepatitis $B$ virus infected patient. J Hepatol 46: 531-538.

Villet S, Pichoud C, Billioud G, Barraud L, Durantel S, Trepo C, Zoulim F. 2008. Impact of hepatitis B virus rtA181 $\mathrm{V} / \mathrm{T}$ mutants on hepatitis B treatment failure. J Hepatol 48: 747-755.

Vlachogiannakos J, Papatheodoridis GV. 2014. HBeAg-negative chronic hepatitis B: Why do I treat my patients with pegylated interferon-alfa? Liver Int 34: 127-132.

Warner N, Locarnini S. 2008. The antiviral drug selected hepatitis B virus rtA181T/sW172* mutant has a dominant negative secretion defect and alters the typical profile of viral rebound. Hepatology 48: 88-98.

Watashi K, Sluder A, Daito T, Matsunaga S, Ryo A, Nagamori S, Iwamoto M, Nakajima S, Tsukuda S, BorrotoEsoda K, et al. 2014. Cyclosporin A and its analogs inhibit hepatitis B virus entry into cultured hepatocytes through targeting a membrane transporter, sodium taurocholate cotransporting polypeptide (NTCP). Hepatology 59: 1726-1737.

Welsch C, Jesudian A, Zeuzem S, Jacobson I. 2012. New direct-acting antiviral agents for the treatment of hepatitis C virus infection and perspectives. Gut 61: i36-i46.

Werle-Lapostolle B, Bowden S, Locarnini S, Wursthorn K, Petersen J, Lau G, Trepo C, Marcellin P, Goodman Z, Delaney WE, et al. 2004. Persistence of cccDNA during 
the natural history of chronic hepatitis B and decline during adefovir dipivoxil therapy. Gastroenterology 126: 1750-1758.

Wong DK, Seto WK, Fung J, Ip P, Huang FY, Lai CL, Yuen MF. 2013. Reduction of hepatitis B surface antigen and covalently closed circular DNA by nucleos $(\mathrm{t})$ ide analogues of different potency. Clin Gastroenterol Hepatol 11: 1004-1010.

Wooddell CI, Rozema DB, Hossbach M, John M, Hamilton HL, Chu Q, Hegge JO, Klein JJ, Wakefield DH, Oropeza CE, et al. 2013. Hepatocyte-targeted RNAi therapeutics for the treatment of chronic hepatitis B virus infection. Mol Ther 21: 973-985.

Wu C-Y, Lin J-T, Ho HJ, Su C-W, Lee T-Y, Wang S-Y, Wu C, Wu J-C. 2014. Association of nucleos(t)ide analogue therapy with reduced risk of hepatocellular carcinoma in patients with chronic hepatitis B-A nationwide cohort study. Gastroenterology 147: 143-151.e5.

Yan H, Zhong G, Xu G, He W, Jing Z, Gao Z, Huang Y, Qi Y, Peng B, Wang H, et al. 2012. Sodium taurocholate cotransporting polypeptide is a functional receptor for human hepatitis B and D virus. eLife 1: e00049.

Yu W, Goddard C, Clearfield E, Mills C, Xiao T, Guo H, Morrey JD, Motter NE, Zhao K, Block TM, et al. 2011 Design, synthesis, and biological evaluation of triazolopyrimidine derivatives as novel inhibitors of hepatitis $\mathrm{B}$ virus surface antigen (HBsAg) secretion. J Med Chem 54: 5660-5670.

Zhang X, Ma Z, Liu H, Liu J, Meng Z, Broering R, Yang D, Schlaak JF, Roggendorf M, Lu M. 2012. Role of Toll-like receptor 2 in the immune response against hepadnaviral infection. J Hepatol 57: 522-528.
Antiviral Therapies of Chronic HBV Infections

Zhu Y, Yamamoto T, Cullen J, Saputelli J, Aldrich CE, Miller DS, Litwin S, Furman PA, Jilbert AR, Mason WS. 2001. Kinetics of hepadnavirus loss from the liver during inhibition of viral DNA synthesis. J Virol 75: 311-322.

Zimmerman KA, Fischer KP, Joyce MA, Tyrrell DL. 2008. Zinc finger proteins designed to specifically target duck hepatitis B virus covalently closed circular DNA inhibit viral transcription in tissue culture. J Virol 82: 80138021.

Zlotnick A, Mukhopadhyay S. 2011. Virus assembly, allostery and antivirals. Trends Microbiol 19: 14-23.

Zoulim F. 2011. Hepatitis: Treatment failure in chronic hepatitis B. Nat Rev Gastroenterol Hepatol 8: 366-367.

Zoulim F. 2012. Are novel combination therapies needed for chronic hepatitis B? Antiviral Res 96: 256-259.

Zoulim F, Locarnini S. 2009. Hepatitis B virus resistance to nucleos(t)ide analogues. Gastroenterology 137: 15931608. e1591-e1592.

Zoulim F, Mason WS. 2012. Reasons to consider earlier treatment of chronic HBV infections. Gut 61: 333-336.

Zoulim F, Saputelli J, Seeger C. 1994. Woodchuck hepatitis virus $\mathrm{X}$ protein is required for viral infection in vivo. $J$ Virol 68: 2026-2030.

Zoulim F, Luangsay S, Durantel D. 2013a. Targeting innate immunity: A new step in the development of combination therapy for chronic hepatitis B. Gastroenterology 144: 1342-1344.

Zoulim F, Testoni B, Lebosse F. 2013b. Kinetics of intrahepatic covalently closed circular DNA and serum hepatitis B surface antigen during antiviral therapy for chronic hepatitis B: Lessons from experimental and clinical studies. Clin Gastroenterol Hepatol 11: 1011-1013. 


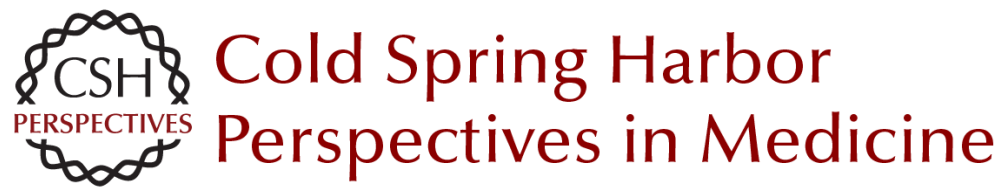

\section{Antiviral Therapies and Prospects for a Cure of Chronic Hepatitis B}

Fabien Zoulim and David Durantel

Cold Spring Harb Perspect Med 2015; doi: 10.1101/cshperspect.a021501

Subject Collection The Hepatitis B and Delta Viruses

Hepatitis B Virus X and Regulation of Viral Gene Expression

Betty L. Slagle and Michael J. Bouchard

The Woodchuck, a Nonprimate Model for Immunopathogenesis and Therapeutic Immunomodulation in Chronic Hepatitis B Virus Infection

Michael Roggendorf, Anna D. Kosinska, Jia Liu, et al.

Mouse Models of Hepatitis B Virus Pathogenesis Matteo lannacone and Luca G. Guidotti

Therapy of Delta Hepatitis

Cihan Yurdaydin and Ramazan Idilman

Immune Response in Hepatitis B Virus Infection Anthony Tan, Sarene Koh and Antonio Bertoletti

Hepatitis D Virus: Introduction and Epidemiology Mario Rizzetto

Management of Chronic Hepatitis B in Patients from Special Populations

Ching-Lung Lai and Man-Fung Yuen

Hepatitis B Virus Genotypes and Variants

Chih-Lin Lin and Jia-Horng Kao
Origins and Evolution of Hepatitis B Virus and Hepatitis D Virus

Margaret Littlejohn, Stephen Locarnini and Lilly Yuen

Assembly and Release of Hepatitis B Virus Lisa Selzer and Adam Zlotnick

Hepatitis D Virus Replication John M. Taylor

Treatment of Liver Cancer

Chun-Yu Liu, Kuen-Feng Chen and Pei-Jer Chen

Hepatitis B Virus and Hepatitis D Virus Entry, Species Specificity, and Tissue Tropism Koichi Watashi and Takaji Wakita

Hepadnavirus Genome Replication and

Persistence Jianming Hu and Christoph Seeger

The Chimpanzee Model for Hepatitis B Virus Infection Stefan F. Wieland

Hepatitis B Virus Epidemiology Jennifer H. MacLachlan and Benjamin C. Cowie

For additional articles in this collection, see http://perspectivesinmedicine.cshlp.org/cgi/collection/ 